\title{
A Market Test for Sex Discrimination: Evidence from Japanese Firm-Level Panel Data
}

\author{
Daiji Kawaguchi ${ }^{1}$ \\ Institute of Policy and Planning Sciences \\ University of Tsukuba \\ Tennodai 1-1-1, Tsukuba, Ibaraki 305-0031, Japan \\ Tel: (81)-29-853-7432 \\ Fax: (81)-29-853-3849 \\ E-Mail:kawaguch@sk.tsukuba.ac.jp
}

July 26, 2003

\footnotetext{
${ }^{1}$ I thank the Ministry of Economy, Trade, and Industry and the Ministry of Public Management, Home Affairs, Posts, and Telecommunications of the Japanese government for releasing the micro data used in this study. I thank Yukiko Abe, Hiroyuki Chuma, Gigi Foster, Hideshi Ito, Yukinobu Kitamura, Sadao Nagaoka, Hisahiro Naito, David Neumark, Fumio Ohtake, Yosuke Okada, and the seminar participants at Osaka Prefecture University, Nagasaki University, Nagoya City University, the Ministry of Economy, Trade, and Industry, the 2003 Spring Meeting of the Japanese Economic Association, Oita, Japan and the 2003 Austrasian Meeting of the Econometric Society, Sydney, Australia for their comments. I thank Donna Maurer for providing an excellent editing service. Errors and omissions remain the fault of the author.
} 


\begin{abstract}
This paper examines the empirical implications of Becker's classical theory of employer discrimination. If the male-female wage differential is due to employer discrimination, then non-discriminatory employers should hire more women and enjoy a higher profit than discriminatory employers. This proposition is tested using Japanese firm-level panel data from the 1990s. The empirical results based on pooled OLS indicate that an increase in the proportion of women employed by a firm enhances its operating profit. These findings are strengthened based on a fixed effects estimation, and this result implies that a firm-specific, time-constant, unobserved high profit factor is negatively correlated with the employment of women. Although employing 10 percentage points more women increases profit by 2.9 percent according to the fixed effects estimates, the cross-sectional estimates indicate almost one-third of the effect because persistently high-profit firms hire fewer women on average. This empirical evidence shows that employing more women increases operating profit, but firms with a persistently high profit factor hire fewer women. The effect of having a high female proportion of total workers is found to be larger in concentrated industries, as implied by Becker's theory.
\end{abstract}




\section{Introduction}

Women's average wage is lower than men's average wage in many countries, and the difference in average wages is very persistent. Researchers have been discussing whether this difference reflects the male-female productivity differential or discrimination against women, which is defined as receiving a lower wage than would be indicated by their productivity. Labor economists regularly regress wage on proxies of productivity, such as educational background or job experience, and examine the unexplained male-female wage gap. They call the unexplained differential "residual discrimination" and typically attribute the difference to sex discrimination. However, there are productivity differences across persons that cannot be observed by econometricians, and these differences may be systematically different across sexes. For example, women with household responsibilities may be less productive in the workplace and thus earn less than men, reflecting their lower productivity (See Becker (1985) for this discussion). Therefore, obtaining a good measure of workers' productivity is very important for making "residual discrimination" compelling evidence for sex discrimination. Labor economists have explored better measures of productivity and produced significant research. Although most of these studies have found evidence for sex discrimination, this evidence is not necessarily definitive, since the perfect measure of each worker's productivity is anywhere from difficult to impossible to obtain. Consequently, it is reasonable to claim that the "residual discrimination" method faces a 
big challenge. (See Altonji and Blank (1999) for a survey of the literature on sex discrimination.)

To circumvent the limitation of the residual discrimination method, several recent studies have implemented the "market test" to identify labor market discrimination against minority workers. This method tests the empirical implications of Becker (1971)'s employer discrimination hypothesis: If majority and minority workers are equally productive but minority workers are paid less, firms can earn more profit by hiring more minority workers. To implement the idea, some measure of a firm's profitability is regressed on the minority employee proportion of the total number of employees. If discrimination against women does not exist, then the female employee proportion should not affect the firm's profitability. On the other hand, if discrimination exists, a higher minority proportion should increase profitability. ${ }^{1}$

Hellerstein, Neumark, and Troske (2002) implemented a market test of sex discrimination using US manufacturing establishment data. They matched the Decennial Census with the Census of Manufacturers and the Annual Survey of Manufacturers by types of industry and location to construct establishment data that included detailed employee information such as female proportion. They found that, holding other variables constant, a 10

\footnotetext{
${ }^{1}$ The other recent method for overcoming the limitation of the residual method is the estimation of production function that regards male and female labor as separate inputs. Then the implied ratio of the female and male marginal product is compared with the ratio of the female and male wage. Hellerstein, Neumark, and Troske (1999) found evidence consistent with female discrimination using US establishment data, while Hellerstein and Neumark (1999) did not find such evidence using Israeli data. Both papers are based on cross-sectional estimates.
} 
percentage point increase in the female proportion increased the operation income/sales ratio by 0.5 of a percentage point, while the average female proportion and operation income/sales ratio were 28.6 percent and 23 percent respectively. Their results were striking because they found a positive correlation between high female proportion and high profitability among firms with strong market power measured by a large product market share, but this positive correlation was not found among firms without market power. This result is consistent with Becker (1971)'s theory because only employers with market power can choose between earning higher profits and hiring fewer women depending on their preference for discrimination.

Although their study made a path-breaking contribution to the literature, there is still some room to improve upon it. As Altonji and Blank (1999) point out in their review, it is crucial to consider the source of variation in female employee proportion across firms. If the source of variation is the difference in the degree of discrimination against women across employers, then the estimator obtained by Hellerstein, Neumark, and Troske (2002) appropriately tests the null hypothesis of no employer discrimination. However, if production technology is heterogeneous across firms and each employer chooses a proportion of female employees to maximize the firm's profit, then the heterogeneity in production technology that may directly affect the firm's profitability is correlated with female proportion. This possible endogeneity of the female proportion makes Hellerstein, Neumark, and Troske (2002)'s estimator biased, leading to a false rejection of the null hypothesis of no em- 
ployer discrimination. This endogeneity could have been circumvented by using a fixed effects estimation, assuming each firm's production technology is time-constant, but they could not do this due to data limitations in the US. In addition, the female proportion can be endogenous due to the Equal Employment Opportunity Act and the different degrees of law enforcement across firm size. Holzer (1998) reported that larger firms hire disproportionately more African American workers than smaller firms. He speculated both stronger law enforcement for larger firms and the exemption of small firms from law enforcement as reasons for his finding. If the same discussion applies to women, then larger firms that arguably enjoy high profitability may hire disproportionately more women to comply with equal opportunity laws.

A series of studies by Ashenfelter and Hannan (1986), Black and Brainerd (2001), and Black and Strahan (2001) also tested the implication of Becker (1971)'s theory that severe market competition leaves less room for employers to indulge their preference for discrimination, thus reducing discrimination against women. Ashenfelter and Hannan (1986) found that banks located in more competitive areas, indicated by a concentration of banks in a geographic region, hire more women. Black and Brainerd (2001) observed that increased imported products in an industry narrowed the male-female wage gap in that industry during the 1980s in the US. In addition, Black and Strahan (2001) showed that deregulation in the banking industry narrowed the malefemale wage gap, exploiting the different timing of deregulation across states for identification. All of these papers consistently showed that competition 
reduces discrimination against women because employers in more competitive industries have less room to indulge their preference for sex discrimination. These studies essentially tested the hypothesis tested by the market test: that employers have a choice between profit and discrimination only when the market is not perfectly competitive.

Szymanski (2000) cleverly implemented a market test of racial discrimination using data from the British Soccer League. He regressed a team's rank in the league on the proportion of black players among team players and the wage bill to players. He found that teams with a higher proportion of black players performed better, holding the wage bill to the players constant. He used panel data to deal with time-constant, unobserved team heterogeneity; thus any heterogeneity within a team that was correlated with black player proportion, such as game style or unobserved difference in inputs other than players, did not bias his market test as long as the heterogeneity was time-constant.

This paper implements the market test for sex discrimination using Japanese, firm-level panel data. The contributions of this paper to the literature are threefold. First and most importantly, the panel data structure assures that the market test will be free from heterogeneity bias. I do not claim that panel data can make the test completely free of all biases, since it does not resolve the simultaneity bias due to demand shock as discussed later. However, the test is "cleaner" than a cross-sectional test and any sign of bias can be much more easily determined using existing knowledge from the research litera- 
ture. In addition, I do not need to match employer and employee records to construct the female proportion in each firm, since firm-level data already contain a male-female breakdown of employees. Second, the survey covers not only manufacturing, but a wide range of industries, assuring the generality of the results. Third, Japan is an ideal country to implement the market test because a) the male-female wage gap is much larger than in Western counties, making the market test powerful if the gap is due to discrimination ${ }^{2}$ and b) the Equal Employment Opportunity legislation that prohibits discrimination against women in recruitment, hiring, job assignment, and promotion became effective in April 1999. ${ }^{3}$ This weak law enforcement arguably assures that the estimator is free from endogeneity bias due to feedback from high profit as a result of higher female employment due to law compliance.

\section{Empirical Strategy}

\section{$2.1 \quad$ Static Test}

\subsubsection{Cross-sectional Estimation}

I estimate the following equation to examine whether a high proportion of female employees increases a firm's profit.

$$
y_{i t}=\beta_{0}+\beta_{1} x_{1 i t}+\beta_{2} x_{2 i t}+\beta_{3} x_{3 i t}+i n d_{i t} \beta_{4}+\operatorname{reg}_{i t} \beta_{5}+\text { year }_{t} \beta_{6}+c_{i}+u_{i t},
$$

\footnotetext{
${ }^{2}$ See Antecol (2001) and Blau and Kahn (2003) for international comparisons of the male-female wage gap.

${ }^{3}$ The original equal opportunity legislation, effective in April 1986, only required that employers make an effort not to discriminate against women.
} 
where subscripts $i$ and $t$ are indexes for firm and year respectively. The dependent variable $y_{i t}$ is a proxy for profitability, defined as operating income/total sales, which is essentially the price-cost margin. Here operating income is calculated by subtracting the sales cost and overhead cost from total sales. Unfortunately, operating income does not correspond to economic profit without subtracting the opportunity cost of capital. The discrepancy between operating income and economic profit depends on each firm's amount of capital. To deal with this issue, I included a fixed assets / total sales ratio, denoted as $x_{2 i t}$ in the regression. The variable $x_{1 i t}$ is the proportion of female employees among the total employees, including part-time workers. To examine whether the heterogeneity of full-time and part-time workers affects the result, the female proportion of full-time workers was used instead of the female proportion of both full- and part-time workers. If discrimination against women exists, then a high female proportion will result in high profit; accordingly, a positive $\beta_{1}$ rejects the null hypothesis of no sex discrimination. The variable $x_{3 i t}$ is the age of the firm. Since older firms tend to hold obsolete capital and the assets/total sales ratio may not capture the capital in the efficiency unit and older firms may hold higher-level intangible capital, such as research and development knowledge or an established brand name, it is important to control for this variable. To capture industrial and regional heterogeneity and time-specific macro shock, industry dummies, pre- 
fecture dummies, and year dummies are included respectively. ${ }^{4}$ The variable $c_{i}$ is the firm-specific, time-constant, and unobserved heterogeneity, and $u_{i t}$ is the idiosyncratic error term.

The assumption

$$
E\left(u_{i t} \mid x_{1 i t}, x_{2 i t}, x_{3 i t}, \text { ind }_{i t}, \text { region }_{i t}, \text { year }_{t}, c_{i}\right)=0
$$

and

$$
E\left(c_{i} \mid x_{1 i t}, x_{2 i t}, x_{3 i t}, \text { ind }_{i t}, \text { region }_{i t}, \text { year }_{t}\right)=0
$$

assures that the OLS estimator is unbiased and consistent. The first assumption excludes the situation in which an idiosyncratic shock to the firmfs profit, such as demand shock, disproportionately affects the number of female and male employees. For example, if women in Japan are marginal workers in a firm, and female employment is more quickly adjusted to the idiosyncratic shock as documented by Houseman and Abraham (1993), then $u_{i t}$ and $x_{1 i t}$ are positively correlated and the OLS estimator of $\beta_{1}$ is upwardly biased. This bias is serious, since the test may spuriously reject the null hypothesis of no discrimination against women. Thus, I suggest a remedy for this bias in the following discussion of the fixed effects estimation.

The second assumption on the conditional expectation of $c_{i}$ is violated when time-constant, firm-specific heterogeneity is correlated with female proportion. If firm-specific, invariable technology affecting profitability also affects female proportion, or if the firm-specific, high profit factor gives em-

\footnotetext{
${ }^{4}$ Industry dummies and regional dummies are allowed to be time variant because a non-negligible number of observations experiences a change in industry code and location.
} 
ployers the opportunity to exercise sex discrimination and some employers discriminate against women, then this second assumption is violated.

\subsubsection{Panel Estimation}

As discussed before, the variation in female employee proportion across firms may result not only from a variation in employers' intent to discriminate based on sex, but also from variations in firms' technology or organizational form. If the firms' unobserved heterogeneity also affects their profit, then the female proportion is endogenous; this makes the OLS estimator biased and the sign of the bias cannot be determined a priori. If factors that affect female employment proportion other than employers' intent to discriminate are time constant, then the endogeneity problem can be resolved by allowing an arbitrary correlation between $c_{i}$ and female proportion by applying a fixed effects estimation to (1). The fixed effects estimator identifies the causation from female employment to profit if $x_{i t}$ varies over time by a change in employers' practice of sex discrimination or some other factors not correlated with firms' profit. More formally, the sufficient condition for the fixed effects estimator to be unbiased is the strict exogeneity of the independent variables from idiosyncratic error (i.e., $E\left(u_{i t} \mid x_{1 i}, x_{2 i}, x_{3 i}\right.$, ind $_{i}$, region $_{i}$, year $\left._{t}, c_{i}\right)=0$, where $x_{i}$ is the vector containing the whole history of $x_{i t}$ of individual $i$.). This assumption rules out the intertemporal correlation of $u_{i t}$ and explanatory variables, as well as any contemporaneous correlation. For example, if the idiosyncratic shock to the profit and female proportion are positively 
correlated, then the market test falsely rejects the null hypothesis of no discrimination. To deal with this endogeneity problem, I include industry-year dummies based on an arguable assumption that the demand shock each firm faces is mostly captured by industry- and year-specific shock. If most of the variation in demand shock across firms is explained by industry- and year-specific shock, then including this industry-year interaction effectively removes the presumable upward bias in the fixed effects estimator.

\subsection{Dynamic Test}

The empirical strategy thus far tests the static implication of Becker (1971)'s hypothesis. Next, I examine whether firms with a high female proportion grow faster because non-discriminatory employers earn higher profits than discriminatory ones, as claimed in Becker (1971). Using the growth of sales or the number of a firm's employees as proxies for a firm's growth, I estimate following equation:

$$
\left(y_{i 1999}-y_{i 1992}\right) / y_{i 1992}=\gamma_{0}+\gamma_{1} x_{1 i 1992}+\gamma_{2} x_{2 i 1992}+i n d \gamma_{3}+r e g \gamma_{4}+u_{i},
$$

where $y_{i t}$ is sales or the number of employees of firm $i$ and time $t, x_{1 i 1992}$ is the female proportion of firm $i$ in year 1992, and $x_{2 i 1992}$ is the age of the firm in year 1992. The industry and prefecture dummies are also included. The long term implication of Becker (1971)'s hypothesis predicts positive $\gamma_{1}$, thus testing the null hypothesis of $\gamma_{1}=0$ is our interest. The sample consists only of those firms that are observed in both 1992 and 1999. To deal with 
probable sample selection bias, I apply Heckman's two-step estimation to $(2)$.

\section{Data}

I used the basic survey of firms' activity collected by the Ministry of Economy, Trade, and Industry (METI) of the Japanese government to implement the test. The survey is a firm-level census survey that covers all firms that hire more than 50 employees and hold more than 30 million yen in capital. The available data cover 6 years, 1992 and every year between 1995 and 1999; and the sample size is about 25,000 firms for each year. From the data sets, I extracted each firm's performance measures, such as total sales, sales cost, or overhead cost, data on the firm's employees, such as the number of full-time employees with sex breakdown, the number of part-time employees with sex breakdown, the book value of its fixed assets, the year of the firm's birth, the prefectural location of the firm, and the three-digit code indicating the industry in which the firm operates. There were originally 152,857 firm-year observations in the 6 years of data, but after excluding observations with missing sales information or inconsistent employee records, there remained 152,774 firm-year observations. The proxy of profitability is the operating income ratio, defined as (total sales - sales costs - overhead costs)/total sales. Since this variable takes extreme value due to the very small amount of total sales, the observations whose operating income ratio was between the 1st percentile and the 99th percentile of its distribution were kept in the 
sample, and there were 149,614 firm-year observations remaining. ${ }^{5}$ Among these 149,614 observations, 40 were dropped because only part-time workers were recorded. This sample restriction reduced the sample size to 149,574 observations with 36,068 companies. This unbalanced panel is the analysis sample for implementing the static test. On the other hand, the dynamic test requires the observations at least for the year 1992. The absolute value of sales and employment growth, which is a proxy for firm growth, takes extreme value due to the small sales amount in 1992, so the sample is also restricted to the observations whose sale and employment growth rate lies below the 99th percentile of its distribution. The remaining 23,182 companies that satisfy these two restrictions are used in the dynamic analysis.

The survey record unfortunately does not distinguish missing values and zero, except when a firm did not answer the whole survey. Since replying to the survey is compulsory due to the Statistics Law and because the METI exerts its best effort to fill in the missing values with a follow-up phone survey, missing values are presumably rare. Thus, all values of zero in the record are treated as actual zeros.

The descriptive statistics of the analysis sample used for the static test are reported in Table 1 . The operating income to sales ratio is 2.42 percent, which is a standard figure for Japanese data. This number is about one-tenth of the US figure reported in Hellerstein, Neumark, and Troske (2002), but it

\footnotetext{
${ }^{5}$ It turned out that this sample restriction was critical in order to obtain the following results.
} 
is known that the profit rate of Japanese firms is lower than that of US firms. ${ }^{6}$ The unweighted mean of firmsf sales growth rate was -4.907 percent between 1992 and 1999, reflecting the long-term recession during that period, and the unweighted mean of employment growth was -1.027 percent accordingly. The female proportion of each firm's total employees was 32.1 percent at the mean.

Table 2 closely examines the yearly labor adjustment. The unweighted mean of the yearly log employment difference is -0.01 ; this number implies that firms have been downsizing their employees by 1 percent annually on average. An examination of the 10th percentile (0.124) and the 90th percentile $(-0.143)$ of the distribution, however, shows the large amount of heterogeneity in the labor adjustment. The number of female employees declined by 2.3 percent annually at the mean, and this number indicates that female workers suffered from recession more severely than men during the 1990s. An examination of the 10th percentile and the 90th percentile of the distribution reveals that the labor adjustment of female workers was more heterogeneous than the male labor adjustment. Female workers are more likely to be subject to employment adjustment probably because they hold less firm- specific human capital and, accordingly, less relation-specific rent. As evidence of this,

\footnotetext{
${ }^{6}$ See, for example, Gugler, Mueller, and Yurtoglu (2002) for an international comparison of the return to investment. The average annual growth rate of firm values in the US was 0.124 between 1985 and 2000 for 8,591 firms, while the rate in Japan was 0.064 during the same period for 2,219 firms. Note that Hellerstein, Neumark, and Troske (2002) restricted their analysis sample to manufacturing establishments, but the current sample contains all industries.
} 
the average tenure in 1997 was 13.3 years among male workers and 8.2 years among female workers (see Table 16 in of Labour (2002)).

The relationship between the change in log total employment and the change in log female employment is plotted in Figure 1. If the observation is on the 45 degree line, the female proportion of total employment did not change over time. Thus, basically, the deviation from the 45 degree line is used to identify the coefficient of the female proportion in the fixed effects estimation. This scatter diagram implies that the data contain sufficient variation in the female worker proportion over time within a firm. The regression coefficient of the change in log female employment on the change in $\log$ total employment is 1.219 , with a standard error of 0.003 . This coefficient implies that the female proportion increases by 2.2 percent on average when total employment grows by 10 percent. $^{7}$

\section{Estimation Results}

\subsection{Static Results}

\subsubsection{Basic Results}

Table 3 Column 1 reports the results of the OLS estimation of the equation (1). The coefficient for the female proportion is $0.24(t=2.00)$. The

\footnotetext{
${ }^{7}$ This finding may raise some doubt that the female proportion is endogenous in the profit equation, since female employment may be more sensitive to demand shock than male employment. However, when I included total employment as an additional explanatory variable in the profit equation as a proxy variable for demand shock, the coefficient for the female proportion reported in the next section did not change essentially. Those results are not reported here.
} 
magnitude of the coefficient implies that a 10 percent increase in the female proportion increases the profit ratio by 0.024 of a percentage point, while the average profit rate is 2.42 percent. Table 2, Column 2 reports the results of the fixed effects estimation. The coefficient for the female proportion becomes as large as $0.89(\mathrm{t}=4.94)$, and this magnitude implies that the 10 percentage points rise in the female proportion increases the profit ratio by 0.088 of a percentage point, which is about 3.6 percent of the average profit rate. The difference between the OLS estimate and the fixed effects estimate implies a negative correlation between the female proportion and unobserved heterogeneity. In other words, firms that have a persistently high profit factor tend to employ fewer women.

This negative association between an unobserved high profit factor and female proportion seems to contradict the prior expectation that new production technology, such as newly developed machines or work organization, may accommodate women well, and, at the same time, render high profit opportunities for firms. However, managers in firms with a persistent high profit factor have more room to choose between higher profits and fewer women in workplace because they feel less pressure from market competition; and some of the discriminatory managers choose a combination of less profit and fewer women. If this is the case, the fixed effects estimator consistently estimates the effect of discrimination. On the other hand, larger fixed effects coefficients than the OLS coefficient may result from the strong, positive correlation between idiosyncratic error and female proportion. Suppose female proportion 
across firms varies due to heterogeneity in the employersf preference for discrimination and the temporary demand shock. As implied by Table 2 and explicitly discussed in Houseman and Abraham (1993), female employment is more sensitive to product demand shock. If the employerfs preference for discrimination does not vary over time, then the source of within variation of the female proportion is totally temporary demand shock. If this is the case, the fixed effects estimator is upwardly biased. However, considering the effect of the equal employment opportunity law enacted in 1986 and the social atmosphere that welcomed female labor participation during the 1990s, there is good reason to believe that the preference for female employment among employers changed during the 1990s. Since both the "more room for discrimination" story and the temporary shock story sound plausible, it would be fair to claim that the OLS estimators estimate the lower bound of the causal effect of discrimination on profit and that the fixed effects estimators estimate the upper bound of the causal effect.

The analysis thus far has ignored the possibility that current positive demand shock increases the current female proportion via more rapid female labor adjustment. To deal with this potential endogeneity of $x_{1 i t}$, I include industry-year dummies in the regression; the dummies capture the demand shock as far as demand shock is common across firms operating in the same three-digit industry in a specific year. Table 2, Column 3 shows the results of the fixed effects estimation with industry-year dummies. The estimated coefficient becomes smaller $(0.72, \mathrm{t}=4.24)$, and this change from the previ- 
ous fixed effect estimate suggests a positive correlation between the current industry-year positive demand shock and the female proportion. Roughly speaking, the 10 percentage point increase in female proportion increases the profit ratio by 0.07 of a percentage point. Considering the average profit ratio of 2.4 percent, this magnitude is still not negligible.

The results thus far have treated full-time workers and part-time workers equivalently. Critics may claim that the previous results merely reflect the causation from a high part-timer proportion to a higher profit because most of the part-timers are women (about 85 percent in the analysis sample). To address this possibility, I re-classified workers into four categories: male full-time workers, female full-time workers, male part-time workers, and female-part time workers, and created a proportion of each type of workers in relation to total workers. Column 4 in Table 3 shows the result of the OLS regression of profit ratio on the full-time female proportion, part-time male proportion, and part-time female proportion, along with the other explanatory variables. The coefficient for the full-time female proportion is $0.35(\mathrm{t}=2.33)$, and this result is consistent with the previous finding. The effects of male and female part-time proportion on profit are not statistically significant. Even after the correlation between firm heterogeneity and the explanatory variables is taken into account by the fixed effects estimation, the coefficient for the full-time female proportion is $0.56(\mathrm{t}=2.80)$, as appears in Column 5 of Table 3. The coefficient for part-time female proportion becomes as large as $1.24(\mathrm{t}=6.20)$. This large coefficient might partly reflect the 
fact that firms encountering positive demand shock adjust their labor force by hiring more female, part-time workers. The result does not change essentially when the industry-year dummies are included, as reported in Column 6 of Table 3. The difference between the OLS estimate and the fixed effects estimate implies that the full-time, female proportion is negatively correlated with a firm-specific, persistent high profit factor. This finding perhaps can be explained by the fact that firms with a persistent high profit factor tend to hire fewer full-time female workers.

To summarize the results, when the female proportion increases by 10 percentage points, and 30 percent of the workers are women in an average firm, the profit rate increases by 0.07 of a percentage point, while the average profit rate is about 2.4 percent, according to the most accepted estimate. Using semi-elasticity, a 10 percentage point increase in female employment increases profit by 2.9 percent. This semi-elasticity is comparable to the US semi-elasticity of 2.1 percent found in Hellerstein, Neumark, and Troske (2002).

To make sense of the size of the estimated most preferable coefficient of 0.72 (Table 3, Column 3), a thought experiment to calculate the upper bound of the effect of female proportion on profit rate is useful. Suppose that the unadjusted male-female wage differential of 0.59 in 1995 is all due to sex discrimination ${ }^{8}$ and male and female workers are perfect substitutes

\footnotetext{
${ }^{8}$ According to statistics from the International Labor Office, average monthly earnings (including bonus payments) of wage earners and salaried employees in the non-agricultural sector was 496.0 thousand yen for men and 252.8 thousand yen for women, whereas hours
} 
in production. The ratio of wage bill to total sales is 0.164 in my data. If the proportion of female is exogenously increased by 10 percentage points while the proportion of male is decreased by 10 percentage points keeping the output level constant, the profit rate should increase by $0.67(=0.41 * 0.164 * 0.1)$ of a percentage point. This number is about nine times as large as the estimated effect. This result implies that not all of the male-female wage differential is due to discrimination, since if it were, the estimated coefficient should have been nine times larger.

\subsubsection{Robustness Check: Concentration}

The fixed effects results presented in the previous section indicated that the female proportion of total employment positively affects firms' profit rates. However, as mentioned before, the female proportion may change over time within a firm, due to factors other than a change in the employers' preference for discriminating against female employees. And if this factor also affects firms' profit rates, then the female proportion becomes endogenous. Although I included industry-year dummies to deal with this possible endogeneity, this may not resolve the endogeneity issue because firm- and time-specific shocks cannot be removed from the industry-year interaction dummies. Thus, in this section, I provide circumstantial evidence that implies that the positive effect of the female proportion on the profit rate is not

of work per week was 38.7 for men and 33.2 for women in 1995. Assuming there are 4.33 weeks in a month, the hourly rate of pay is 2.96 thousand yen for men and 1.76 thousand yen for women. 
a merely spurious correlation. ${ }^{9}$

According to Becker's discussion, if firms in an industry face tense market competition, only non-discriminatory employers survive, since the firms that do not maximize their profit are immediately kicked out of the market. Thus we should not find a positive effect of female proportion on the profit rate among firms that operate in competitive industries. On the other hand, an uncompetitive market structure leaves room for employers to make choices on the female proportion and profit rate. Employers choose an optimal mix of female proportion and profit rate to maximize their utility, and, as a consequence, female proportion should have a positive impact on the profit rate. I test this prediction by examining whether the effect of female proportion on the profit rate is larger for firms operating in concentrated industries. As a proxy for the degree of competition among industries, the Herfindahl index from 1992 is used. ${ }^{10}$ The Herfindahl index at the beginning of the survey is used to avoid possible endogeneity of the Herfindahl index due to demand shock or other shocks. The analysis sample is divided into four categories of industries depending on the Herfindahl index in 1992. The first category includes industries whose Herfindahl index is below the 25th percentile of the index distribution. The second, third, and fourth categories include industries between the 25th and 50th percentiles, the 50th and 75th percentiles,

\footnotetext{
${ }^{9}$ A similar test was implemented in Hellerstein, Neumark, and Troske (2002).

${ }^{10}$ The Herfindahl index is the squared sum of each firm's market share, defined for each three-digit industry. The market share is calculated based on each firmfs final goods shipment. A higher number on the Herfindahl index implies a higher concentration in the industry.
} 
and the 75 th percentile and above of the index distribution respectively. I call each category 1 . least concentrated industries, 2. less concentrated industries, 3. moderately concentrated industries, and 4. most concentrated industries.

The estimation results of the profit function, using each category of the degree of industry concentration, appear in Table 4. Panel A, Columns 1 and 2, reports OLS and fixed effects estimation results for the sample of least concentrated industries. Estimated coefficients by both OLS nor fixed effects are not statistically significant. The inclusion of the part-time and full-time breakdown does not change the results, as reported in Columns 3 and 4. Panel B reports the estimation results for the less concentrated industries. Although the estimated coefficient by OLS is not statistically significant, the estimated coefficient by fixed effects become larger, up to 1.02 with statistical significance $(t=2.68)$, as reported in Column 2. The fixed effects results using the full-time and part-time breakdown reported in Column 4 indicate that the coefficient for part-time female workers is larger than that of full-time female workers; however, the coefficient for the proportion of full-time female workers is still as large as 0.77 , with marginal statistical significance $(t=1.83)$. Panel $\mathrm{C}$ reports the estimated results using the sample from moderately concentrated industries. Focusing on the fixed effects results reported in Column 2, the coefficient for proportion female is $2.24(t=4.67)$, and this magnitude is even larger than estimated coefficients from previous samples. The results obtained thus far are consistent with 
the prediction from Becker's theory: A positive, partial correlation between female proportion and profit rate should only be found in less competitive (more concentrated) industries. Panel D reports the estimated results for the most concentrated industries. The estimated coefficient for proportion female by the fixed effects is smaller than the previous sample, but it is still as large as 1.08 and statistically significant $(t=2.51)$. However some caution is necessary, since the fixed effects analysis reported in Column 4 using the fulltime and part-time classification indicates that the large estimated coefficient for proportion female in Column 2 is due to a large coefficient for proportion part-time female.

To summarize, the analysis with the divided sample by industry concentration found the positive partial correlation between proportion female and profit rate in less and moderately concentrated industries, but the positive correlation was not detected in the least concentrated industries. The results for the most concentrated industries are somewhat mixed, but there was weak evidence for a positive, partial correlation between proportion female and profit rate.

The findings obtained using the Harfindahl index implies that the positive correlation between female proportion and profit rate in the previous section is roughly consistent with Becker's employer discrimination theory. 


\subsubsection{Robustness Check: Random Growth Model}

The fixed effects estimation in the previous analysis allowed for time-invariant, firm-specific heterogeneity that is arbitrarily correlated with female proportion. However, there is a good reason to suspect that the firm-specific heterogeneity in the profit growth rate is correlated with female proportion. As evidenced in Figure 2, a one percent increase in total employment is associated with a 1.2 percent increase in female employment on average. Thus, the female proportion may be high among growing firms and this positive correlation between female proportion and the firm-specific growth rate causes an upward bias of the fixed effects estimator. To deal with this possibility, the following random growth model is estimated:

$$
y_{i t}=\beta_{0}+\beta_{1} x_{1 i t}+\beta_{2} x_{2 i t}+\beta_{3} x_{3 i t}+i n d_{i t} \beta_{4}+\operatorname{reg}_{i t} \beta_{5}+y_{e a r_{t}} \beta_{6}+c_{i}+a_{i} t+u_{i t},
$$

where $a_{i}$ is the firm-specific growth rate that may be correlated with explanatory variables in arbitrary ways. The model is estimated by applying the fixed effects estimation to the data with first difference transformation. The estimation renders an unbiased and consistent estimator of $\beta$ if the strict exogeneity of the idiosyncratic error (i.e. $E\left(u_{i t} \mid x_{i}\right.$, ind $_{i}$, reg $_{i}$, year $\left._{t}, c_{i}, a_{i}\right)=0$ ) holds.

The results of the estimation appear in Table 5. The estimated coefficient by random growth model becomes larger than the fixed effects estimate. The estimated coefficient in Column 1 implies that a 10 percentage point increase in the female proportion increases the profit rate by 0.1 of a percentage point. 
The change in the estimated coefficient from the fixed effects estimate implies a negative correlation between female proportion and the unobserved, firmspecific growth rate, $a_{i}$. This is consistent with the finding in the next section: The firms with a high female proportion in 1992 were more likely to drop off from the sample in 1999. Thus females are more likely to be employed in firms that have low or negative underlying growth rates. However, given a firm's low or negative growth rate, hiring more women increases its profit. The result of the estimation that allows for industry-year specific shock is reported in Column 2. Although the coefficient becomes smaller as expected, the result does not essentially change.

The estimation results using the full-time and part-time classification as explanatory variables that are reported in Column 3 and 4 are interesting. Once the firm-specific growth rate is allowed to be correlated with female proportion, the estimation result reported in Column 3 implies that hiring 10 percentage points more full-time female workers increases the profit rate by 0.95 of a percentage point $(\mathrm{t}=4.32)$, when industry-year dummies are not included. The result is essentially the same even when industry-year dummies are included, as reported in Column 4.

The estimated results of the random growth model offer additional evidence that a rise in the female proportion increases the profit rate in a causal sense. 


\subsection{Dynamic Results}

In this section, I examine whether a firm that hires more women will grow at faster rate due to higher profit by estimating the equation (2) from the previous section. If non-discriminatory firms purge discriminatory firms from markets, then a perfectly competitive market eliminates discrimination against women as predicted by Becker (1971). Firms that report positive numbers of sales and employees in both 1992 and 1999 are classified as "survivors" and are used to estimate the equation (2); in other words, the sample selection is based on the criteria that firms employed more than 50 employees and held at least 30 million yen in capital in both 1992 and 1999 and reported positive numbers of sales and employees. To account for this incidental sample selection, I estimate the survival probability in 1999 conditioned on the observation available in 1992 by probit estimation in the first stage; I then estimate (2) by OLS, including the inverse mill's ratio calculated from the first stage probit. Since employment growth or sales growth almost determines survival, it is logically inconsistent to look for the excluded variables in the selection equation. Accordingly, I include the same set of variables in the first stage probit and the second stage OLS; thus it should be noted that the identification of coefficients in (2) depends on the non-linearity of the inverse mill's ratio.

Table 4, Column (1) tabulates the results of the probit regression of survival in 1999, conditioned on the firms' characteristics in 1992. The female proportion negatively affects firms' survival; a 10 percent increase in the fe- 
male proportion decreases the survival probability by 1.1 percent, while the survival rate is about 71 percent. However, once survival is conditioned, an increase in the female proportion positively affects firms' sales growth, as shown in Column (2); a 10 percent increase in female proportion increases firms' sales by 0.69 of a percentage point $(t=1.52)$, while the average sale growth rate conditioned on survival is -4.91 percent. The female proportion also positively affects employment growth, although the estimated effect is not statistically significant (Column (3)). Similar results are obtained when the detailed re-classification of workers is used as a set of explanatory variables. Column (4) shows that a 10 percentage point increase in the female proportion reduces firms' survival probability by 1.1 percentage points. Columns (5) and (6) show that the full-time female proportion in 1992 positively affected both sales and employment growth, but the effects are not statistically significant.

The results of the growth regression are consistent with the results obtained in the previous analysis; firms with a persistently high profit factor hire fewer women. If the persistently high profit is due to the market structure of the industry in which the firm operates or the firmsf non-transferable technology, then firms without this persistent high profit factor do not necessarily perform better in the long run just because they hire more women and earn more profit. If the corporate governance structure is such that the shareholders' benefit is maximized, then the rent due to market structure or technology goes to the shareholders, and managers have no room to in- 
dulge their preference for discrimination. The empirical results in this section suggest that markets are not competitive enough to eliminate sex discrimination and corporate governance structures seem to leave room for managers to enjoy the rent.

\section{Conclusion}

Becker (1971) proposed the model of employer discrimination, which indicated that a discriminatory employer hires fewer women than would be necessary for attaining the profit maximizing level in order to indulge their preference for discrimination. This paper examined whether firms with a higher female proportion earn higher profits in order to test the empirical implication of this theory. Firm-level, panel data from Japan covering a sixyear period were used to implement the test. The empirical results showed that a rise in female employment increases the profit ratio, defined by the operating income/sales ratio. A fixed effects estimation to deal with correlated, unobserved firm characteristics rendered even stronger results: A 10 percentage point increase in female proportion increases the profit rate by 2.9 percent. This result implies that a time-constant, firm-specific high profit factor is negatively correlated with female employee proportion. This result supports employer discrimination as an explanation for the male-female wage gap. The effect of a high female proportion on high profit rate is found to be stronger in concentrated industries.

Becker (1971)'s employer discrimination hypothesis has a long- run im- 
plication that employers who do not discriminate purge the discriminatory employers because the former firms earn more profits. This long-run implication was tested by examining whether the firms hiring more women grow faster than the firms hiring fewer women. The result of this test indicated that the initial level of female employment does not induce firm growth, which is measured by sales growth or growth of the number of employees. This result is consistent with the negative correlation between the unobserved high profit factor and female proportion implied by the difference between the OLS and the fixed effects estimates. Even if a non-discriminatory firm hires more women, the firm's profit does not necessarily exceed that of a firm with a persistent high profit factor (e.g., non-transferable technology or industrial market structure). Taking this negative correlation of persistent high profit and female proportion into consideration, the long-run implication of Becker (1971)'s employer discrimination theory does not necessarily hold. As long as a persistently high profit factor exists and some rent is imputed to discriminatory employers, the male-female wage gap can be persistent.

The empirical results obtained in this study are interesting because they suggest a mechanism by which employer discrimination and a male-female wage gap coexist. Further theoretical and empirical analysis of the reasons why high-profit firms hire fewer women may be an important future research topic. 


\section{References}

Altonji, J. G., And R. M. Blank (1999): Handbook of Labor Economicsvol. 3C, chap. Race and Gender in the Labor Market. Elsevier.

Antecol, H. (2001): "Why is There Interethnic Variation in the Gender Wage Gap?," Journal of Human Resources, 36(1), 119-143.

Ashenfelter, O., and T. Hannan (1986): "Sex Discrimination and Product Market Competition: The Case of the Banking Industry," Quarterly Journal of Economics, 101, 149-173.

Becker, G. S. (1971): The Economics of Discrimination 2nd Edition. University of Chicago Press.

(1985): "Human Capital, Effort, and the Sexual Division of Labor," Journal of Labor Economics, 3(1), S33-S58.

Black, S. E., And E. Brainerd (2001): "Importing Equality? The Effects of Increased Competition on the Gender Wage Gap," Federal Reserve Bank of New York Staff Report 74.

Black, S. E., And P. E. Strahan (2001): "The Division of Spoils: RentSharing and Discrimination in a Regulated Industry," American Economic Review, 91(4), 814-831.

Blau, F. D., AND L. M. KAHN (2003): "Understanding International Dif- 
ferences in the Gender Pay Gap," Journal of Labor Economics, 21(1), $106-144$.

Gugler, K. D., C. Mueller, and B. B. Yurtoglu (2002): "Corporate Governance, Capital Market Descipline and the Returns on Investment," University of Vienna.

Hellerstein, J. K., And D. Neumark (1999): "Sex, Wages and Productivity: An Empirical Analysis of Israeli Firm-Level Data," International Economic Review, 40(1), 95-123.

Hellerstein, J. K., D. Neumark, and K. R. Troske (1999): "Wages, Productivity, and Worker Characteristics: Evidence from Plant-Level Production Functions and Wage Equations," Journal of Labor Economics, $37(2), 409-446$.

- (2002): "Market Forces and Sex Discrimination," Journal of Human Resources, 37(2), 896-914.

Holzer, H. J. (1998): "Why Do Small Establishments Hire Fewer Blacks than Large Ones?," Journal of Human Resources, 33(4), 896-914.

Houseman, S. N., and K. G. Abraham (1993): "Female Workers as a Buffer in the Japanese Economy," American Economic Review, 83(2), $45-51$.

OF Labour, J.-I. (2002): Japanese Working Life Profile. Japan-Instituteof-Labour. 
Szymanski, S. (2000): "A Market Test for Discrimination in the English Professional Soccer Leagues," Journal of Political Economy, 108(3), 590603. 
Table 1: Descriptive Statistics, All Firms, 1992, 1995-1999

\begin{tabular}{lcc}
\hline & Mean & S.D. \\
\hline Operating Income / Sales (\%) & 2.42 & 4.12 \\
Sales Growth Rate (\%) 1992-1999 | Survival (N=16377) & -4.91 & 35.08 \\
Total Employment Growth Rate (\%)1992-1999 | Survival (N=16377) & -1.03 & 30.01 \\
Proportion Full-time Female & 0.23 & 0.16 \\
Proportion Part-time Male & 0.02 & 0.05 \\
Proportion Part-time Female & 0.09 & 0.15 \\
Firm Age & 0.34 & 0.87 \\
Fixed Assets / Total Sales & 35.29 & 14.41 \\
Herfindahl Index in 1992 & 0.03 & 0.03 \\
Number of Firms & 36070 & - \\
Number of Observations & 149614 & - \\
\hline
\end{tabular}

Note: The sample includes observations with operating income / sales ratios between the 1st and 99th percentiles of the distribution. Only for the sales and employment growth rate, the observations available for 1992 and 1999 are selected; in addition, observations whose sales and employment growth rate lie below the 99th percentile of the distribution are kept in the sample. 
Table 2: Labor Adjustment during the 1990s: 1992, 1995-1999, Pooled

\begin{tabular}{lcccccc}
\hline & Mean & $\begin{array}{c}\text { Standard } \\
\text { Deviation }\end{array}$ & Median & $\begin{array}{c}\text { 10th } \\
\text { Percentile }\end{array}$ & $\begin{array}{c}\text { 90th } \\
\text { Percentile }\end{array}$ & $\mathrm{N}$ \\
\hline$\Delta$ Log Total & -0.01 & 0.18 & -0.01 & -0.14 & 0.12 & 113529 \\
$\Delta$ Log Total (Weighted) & -0.02 & 0.21 & -0.02 & -0.14 & 0.10 & 113529 \\
$\Delta$ Log Female & -0.02 & 0.30 & -0.02 & -0.27 & 0.21 & 113529 \\
$\Delta$ Log Female (Weighted) & -0.04 & 0.32 & -0.03 & -0.25 & 0.16 & 113529 \\
\hline
\end{tabular}

Note: Firm size before labor adjustment is used as the weight for weighted statistics. The sample is restricted to those firms observed in two consecutive years. 
Table 3: The Determination of Profit Rate (Operating Income / Total Sales, Percentage)

\begin{tabular}{lcccccc}
\hline & $(1)$ & $(2)$ & $(3)$ & $(4)$ & $(5)$ & $(6)$ \\
\hline Model & OLS & FE & FE & OLS & FE & FE \\
Proportion Female & 0.24 & 0.89 & 0.72 & - & - & - \\
& $(0.12)$ & $(0.18)$ & $(0.17)$ & & & \\
Proportion Full-time Female & - & - & - & 0.35 & 0.56 & 0.45 \\
& & & & $(0.15)$ & $(0.20)$ & $(0.19)$ \\
Proportion Part-time Male & - & - & - & -0.41 & 0.32 & 0.16 \\
& & & & $(0.30)$ & $(0.26)$ & $(0.26)$ \\
Proportion Part-time Female & - & - & - & 0.13 & 1.24 & 1.01 \\
& & & & $(0.14)$ & $(0.20)$ & $(0.19)$ \\
Firm Age & -0.01 & - & - & -0.01 & - & - \\
& $(0.00)$ & & & $(0.00)$ & & \\
Fixed Assets / Total Sales & 0.19 & -0.10 & -0.09 & 0.19 & -0.10 & -0.09 \\
& $(0.09)$ & $(0.01)$ & $(0.01)$ & $(0.09)$ & $(0.01)$ & $(0.01)$ \\
Constant & 5.30 & 2.93 & 3.06 & 5.29 & 2.98 & 3.10 \\
& $(1.30)$ & $(1.15)$ & $(0.69)$ & $(1.30)$ & $(1.15)$ & $(0.69)$ \\
Ind. * Year Dummies & No & No & Yes & No & No & Yes \\
$\mathrm{R}^{2}$ & 0.11 & - & - & 0.11 & - & - \\
Number of Firms & 36070 & 36070 & 36070 & 36070 & 36070 & 36070 \\
Number of Observations & 149614 & 149614 & 149614 & 149614 & 149614 & 149614 \\
\hline
\end{tabular}

Note: Standard errors are in parentheses under the regression coefficients. OLS standard errors are robust against panel clustering. All specifications include three-digit industry, prefecture, and year dummies. 
Table 4: The Determination of Profit Rate: Sample Division by Concentration Panel A: Least Concentrated Industries (Harfindahl Index is less than the 25th percentile)

\begin{tabular}{lcccc}
\hline & $(1)$ & $(2)$ & $(3)$ & $(4)$ \\
\hline Model & OLS & FE & OLS & FE \\
Proportion Female & 0.36 & 0.31 & - & - \\
& $(0.25)$ & $(0.35)$ & & \\
Proportion Full-time Female & - & - & 0.58 & 0.21 \\
& & & $(0.34)$ & $(0.40)$ \\
Proportion Part-time Male & - & - & -0.53 & 0.23 \\
& & & $(0.63)$ & $(0.48)$ \\
Proportion Part-time Female & - & - & 0.23 & 0.39 \\
& & & $(0.25)$ & $(0.36)$ \\
Observations & 27285 & 27285 & 27285 & 27285 \\
Number of Firms & 5719 & 5719 & 5719 & 5719 \\
$\mathrm{R}^{2}$ & 0.12 & - & 0.12 & - \\
\hline
\end{tabular}

Panel B: Less Concentrated Industries (Harfindahl Index is equal to or more than the 25th percentile and less than the 50th percentile)

\begin{tabular}{lcccc}
\hline & $(1)$ & $(2)$ & $(3)$ & $(4)$ \\
\hline Model & OLS & FE & OLS & FE \\
Proportion Female & 0.29 & 1.02 & - & - \\
& $(0.27)$ & $(0.38)$ & & \\
Proportion Full-time Female & - & - & 0.45 & 0.77 \\
& & & $(0.33)$ & $(0.42)$ \\
Proportion Part-time Male & - & - & 0.52 & 0.98 \\
& & & $(0.82)$ & $(0.65)$ \\
Proportion Part-time Female & - & - & 0.05 & 1.32 \\
& & & $(0.33)$ & $(0.44)$ \\
Observations & 31033 & 31033 & 31033 & 31033 \\
Number of Firms & 6512 & 6512 & 6512 & 6512 \\
$\mathrm{R}^{2}$ & 0.15 & - & 0.15 & - \\
\hline
\end{tabular}

Note: The same note applies as appears in Table 3. 
Panel C: Moderately Concentrated Industries (Harfindahl Index is equal to or more than the 50th percentile and less than the 75 th percentile)

\begin{tabular}{lcccc}
\hline & $(1)$ & $(2)$ & $(3)$ & $(4)$ \\
\hline Model & OLS & FE & OLS & FE \\
Proportion Female & 0.70 & 2.24 & - & - \\
& $(0.34)$ & $(0.48)$ & & \\
Proportion Full-time Female & - & - & 0.67 & 1.47 \\
& & & $(0.42)$ & $(0.53)$ \\
Proportion Part-time Male & - & - & -0.78 & 0.72 \\
& & & $(0.78)$ & $(0.76)$ \\
Proportion Part-time Female & - & - & 0.76 & 3.37 \\
& & & $(0.43)$ & $(0.57)$ \\
Observations & 25766 & 25766 & 25766 & 25766 \\
Number of Firms & 5246 & 5246 & 5246 & 5246 \\
$\mathrm{R}^{2}$ & 0.14 & - & 0.14 & - \\
\hline
\end{tabular}

Panel D: Most Concentrated Industries (Harfindahl Index is equal to or more than the 75th percentile)

\begin{tabular}{lcccc}
\hline & $(1)$ & $(2)$ & $(3)$ & $(4)$ \\
\hline Model & OLS & FE & OLS & FE \\
Proportion Female & -0.44 & 1.08 & - & - \\
& $(0.27)$ & $(0.43)$ & & \\
Proportion Full-time Female & - & - & -0.64 & 0.35 \\
& & & $(0.30)$ & $(0.46)$ \\
Proportion Part-time Male & - & - & -0.63 & 0.32 \\
& & & $(0.83)$ & $(0.72)$ \\
Proportion Part-time Female & - & - & -0.08 & 2.31 \\
& & & $(0.36)$ & $(0.50)$ \\
Observations & 29729 & 29729 & 29729 & 29729 \\
Number of Firms & 6053 & 6053 & 6053 & 6053 \\
$\mathrm{R}^{2}$ & 0.11 & - & 0.11 & - \\
\hline
\end{tabular}

Note: All specifications include firm age, fixed assets / total sales, three-digit industry, prefecture, and year dummies as additional control variables. 
Table 5: The Determination of Profit Rate: Random Growth Model

\begin{tabular}{|c|c|c|c|c|}
\hline \multirow{3}{*}{ Model } & (1) & (2) & (3) & (4) \\
\hline & Random & Random & Random & Random \\
\hline & Growth & Growth & Growth & Growth \\
\hline Female Ratio & $\begin{array}{c}1.05 \\
(0.20)\end{array}$ & $\begin{array}{c}0.94 \\
(0.20)\end{array}$ & - & - \\
\hline Female Full-time Ratio & - & - & $\begin{array}{c}0.95 \\
(0.22)\end{array}$ & $\begin{array}{c}0.86 \\
(0.22)\end{array}$ \\
\hline Male Part-time Ratio & - & - & $\begin{array}{c}0.41 \\
(0.29)\end{array}$ & $\begin{array}{c}0.36 \\
(0.28)\end{array}$ \\
\hline Female Part-time Ratio & - & - & $\begin{array}{c}1.23 \\
(0.23)\end{array}$ & $\begin{array}{c}1.07 \\
(0.22)\end{array}$ \\
\hline Fixed Assets / Total Sales & $\begin{array}{l}-0.14 \\
(0.02)\end{array}$ & $\begin{array}{l}-0.12 \\
(0.02)\end{array}$ & $\begin{array}{l}-0.14 \\
(0.02)\end{array}$ & $\begin{array}{l}-0.12 \\
(0.02)\end{array}$ \\
\hline Constant & $\begin{array}{c}2.60 \\
(1.86)\end{array}$ & $\begin{array}{c}3.99 \\
(2.45)\end{array}$ & $\begin{array}{c}2.60 \\
(1.86)\end{array}$ & $\begin{array}{c}3.99 \\
(2.45)\end{array}$ \\
\hline Ind. * Year Dummies & No & Yes & No & Yes \\
\hline Observations & 113544 & 113544 & 113544 & 113544 \\
\hline Number of Firms & 30601 & 30601 & 30601 & 30601 \\
\hline
\end{tabular}

Note: Standard errors are in parentheses. All specifications include three-digit industry, prefecture, and year dummies. The fixed effects estimation was applied to first differenced data. The sample is accordingly restricted to observations available for two consecutive years and $\mathrm{T}>=3$. 
Table 6: The Determination of Sales Growth

\begin{tabular}{|c|c|c|c|c|c|c|}
\hline & (1) & (2) & (3) & (4) & (5) & (6) \\
\hline Dependent Variable (\%) & Survival & Sales & Emp. & Survival & Sales & Emp. \\
\hline Model & Probit & Heckit & Heckit & Probit & Heckit & Heckit \\
\hline Value in 1992 & & & & & & \\
\hline Proportion Female & $\begin{array}{l}-0.11 \\
(0.02)\end{array}$ & $\begin{array}{c}0.90 \\
(4.55)\end{array}$ & $\begin{array}{l}-4.10 \\
(3.97)\end{array}$ & - & - & - \\
\hline Proportion Full-time Female & - & - & - & $\begin{array}{l}-0.11 \\
(0.02)\end{array}$ & $\begin{array}{l}-0.54 \\
(4.82)\end{array}$ & $\begin{array}{l}-8.20 \\
(4.20)\end{array}$ \\
\hline Proportion Part-time Male & - & - & - & $\begin{array}{l}-0.11 \\
(0.08)\end{array}$ & $\begin{array}{l}21.14 \\
(7.96)\end{array}$ & $\begin{array}{l}-25.34 \\
(6.93)\end{array}$ \\
\hline Proportion Part-time Female & - & - & - & $\begin{array}{l}-0.10 \\
(0.03)\end{array}$ & $\begin{array}{l}17.30 \\
(4.58)\end{array}$ & $\begin{array}{c}3.65 \\
(3.99)\end{array}$ \\
\hline Firm Age & $\begin{array}{c}0.004 \\
(<0.000)\end{array}$ & $\begin{array}{l}-0.47 \\
(0.14)\end{array}$ & $\begin{array}{l}-0.31 \\
(0.12)\end{array}$ & $\begin{array}{c}0.004 \\
(0.000)\end{array}$ & $\begin{array}{l}-0.45 \\
(0.14)\end{array}$ & $\begin{array}{l}-0.32 \\
(0.12)\end{array}$ \\
\hline Inverse Mill's Ratio & - & $\begin{array}{c}-7.15 \\
(26.10)\end{array}$ & $\begin{array}{c}5.86 \\
(22.75)\end{array}$ & - & $\begin{array}{c}-5.95 \\
(25.96)\end{array}$ & $\begin{array}{c}2.91 \\
(22.66)\end{array}$ \\
\hline Number of Observation & 23182 & 23182 & 23182 & 23182 & 23182 & 23182 \\
\hline
\end{tabular}

Note: All specifications include three-digit industry dummies and prefecture dummies. Marginal effects are reported for the probit estimation. The standard errors are in parentheses. Heckit estimates are two-step estimates that use the probit estimation reported in columns (1) and (4) as the first stage, probit regression. The sample is restricted to those observations whose sales employment growth rates are below the 99th percentile of the distribution. Among the 23,182 firms in 1992, 16,377 firms were observed in 1999. 
Figure 1: The Change in Log Total Employment and Log Female Employment

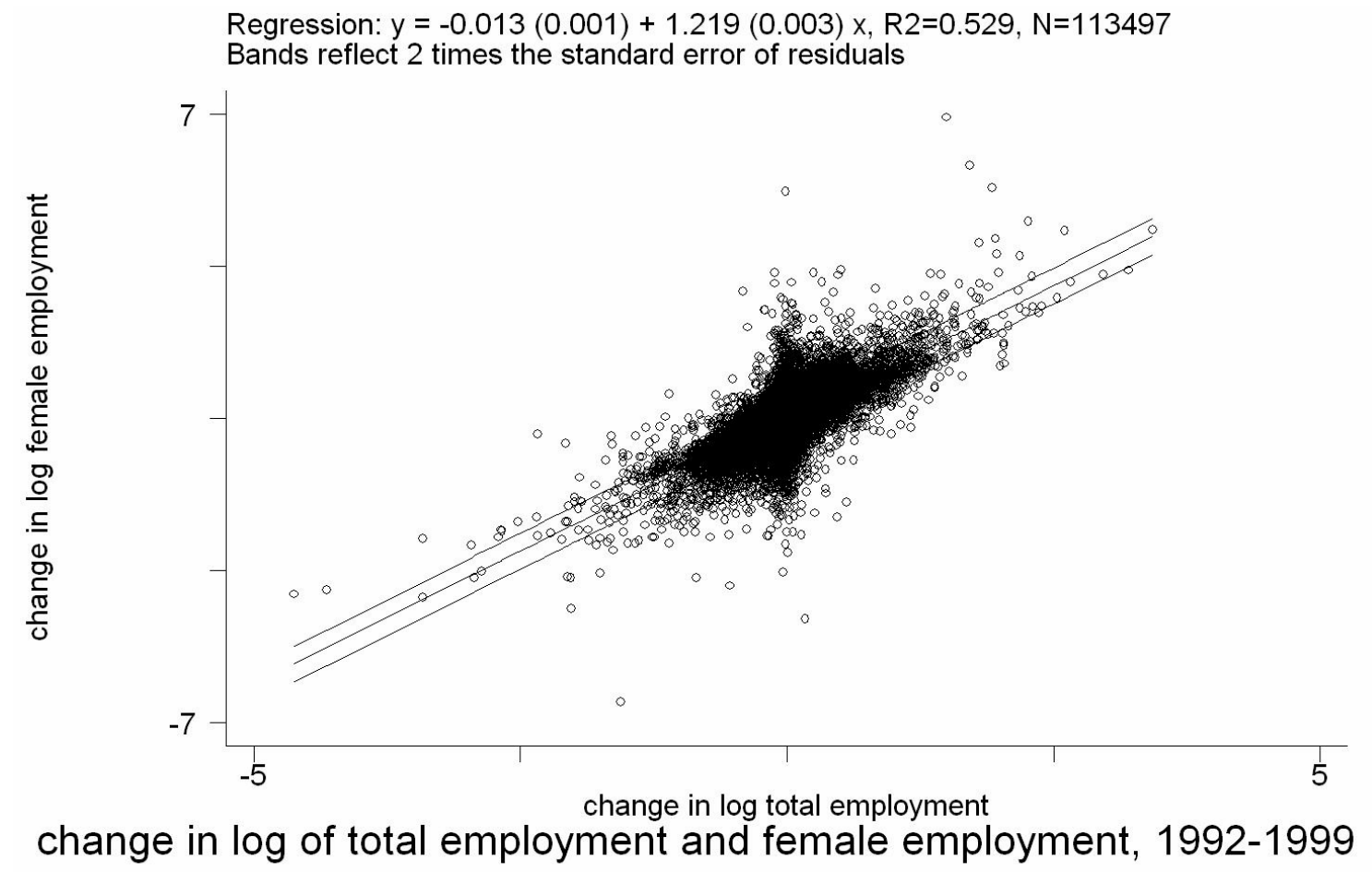

